\title{
NEW ENGLAND RECORDS FOR ERITETTIX CARINATUS SCUDDER AND CONOCEPHALUS TRIOPS LINN.
}

\author{
BY W. E. BRITTON, NEW HAVEN, CONN.
}

THE following species of Orthoptera, from the collection of the Connecticut Agricultural Experiment Station at New Haven, the writer believes have not hitherto been reported from Connecticut. Mr. A. P. Morse of Wellesley, Mass. has recently examined the doubtful material which the collection contained in this order, and I am indebted to him for making the determinations.

\section{Eritettix carinatus Scudder.}

Two adults : one taken by my assistant, Mr. B. H. Walden, at Southington June 30,1903 , in a dry field of grass and weeds. The other was taken at New Haven, June 16, 1902, by Mr. E. J. S. Moore, a temporary field assistant. Mr. Moore also took half grown specimens on October $3 \mathrm{I}, 1902$, at MI. Carmel, nine miles north of New Haven, and on October 30, and November 2, 1902, at Maltby Park, in the town of Orange about three miles west of New Haven. Mr. Morse states (in Litt.) that this is the first New England record for the species.

\section{Conocephalus triops Linn.}

A single specimen taken by Mr. Walden in dry open fields near the Experiment Station at New Haven, October 3, 1902. This is the first undoubtedly native example to be recorded.

\section{BOOK REVIEW.}

The Orthoptera of Indiana. An illustrated descriptive catalogue of the species known to occur in the state, with bibliography, synonymy, and descriptions of new species. By W. S. Blatchley, State Geologist. Author's separate (Sept., 1903) from $27^{\text {th }}$ ann. rep. dep. geol. and nat. res. Ind., 1902, pp. 123-47 1 + index, 3 pl., 122 cuts. Indianapolis, Ind.

This is distinctly the best account of the orthopterous fauna of a single state, prepared by a state official, and issued by the state, that has yet appeared, and forms an excellent example for others to follow. A similar work from each of the 
larger states is a great desideratum. This is, however, impracticable. Prof. Blatchley has made a special study of the group for a number of years and brings to the preparation of this work experience such as few have and that can be gained in no other way.

The work is practical in plan, clear and simple in diction, attractive, readable, and altogether well adapted for use by the average person seeking information upon the subject. It contains much biological information secured at first hand during an extended experience in the field, and will be found invaluable to any student of the group as found in the central states, and to the special student as well. It contains a map of the state showing where collecting has been done, an introductory chapter on the external anatomy, life history and enemies of orthoptera, a very full bibliography, a brief but adequate glossary, and a chapter on the life zones of the state. Under each species are given its scientific and common names, a brief synonymy with references to the more important literature, its description, distribution, and bioiogy. New species are described in Blattidae, Acridiidae, Locustidae, and Gryllidae. The plates and figures, derived chiefly from other sources, illustrate more or less effectively the more important genera and species, diagnostic characters, etc., and the pink form of a katydid in color.

The typography, though equal to the average in works from such sources, might have been much improved. A few errors and inadvertencies need correction, notably the use of tegmina for tegmen (pp. $135-6$ ) and the repeated misspelling of Dichromorpha.

The chapter on the life zones is the only one which calls for especial remark or criticism here. The statements regarding the sources of the Indiana fauna and the relation of the species composing it to the life zones must be taken tentatively in details until fuller knowledge is avaiiable. Though several families of the group, - the Acridiidae in particular - are exceptionally valuable for the study of this problem it is impossible to draw correct conciusions on such points from study of a limited area, and the extralimital distribution of several of the species is widely at variance with the conclusions stated.-A. P. MORSE. 

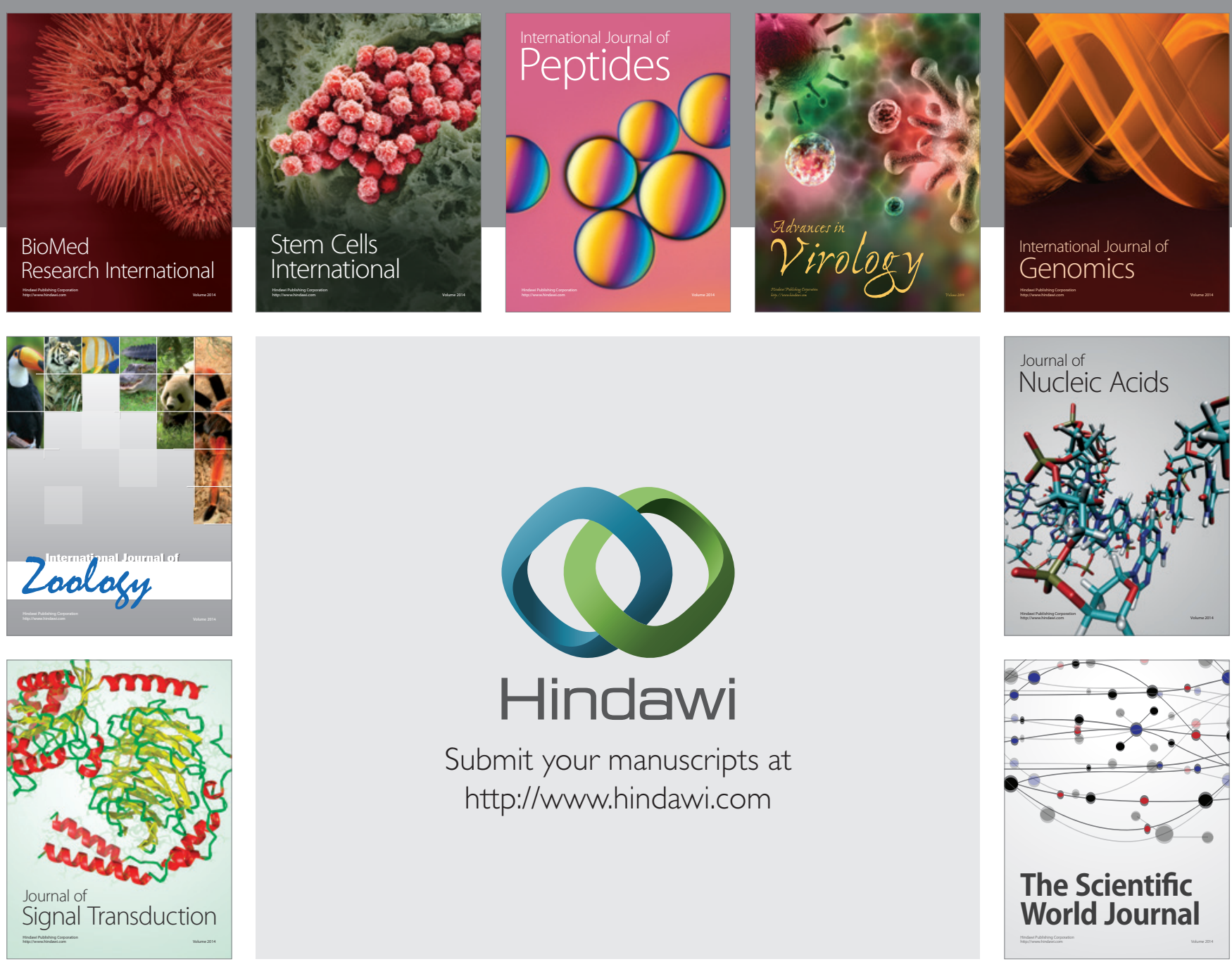

Submit your manuscripts at

http://www.hindawi.com
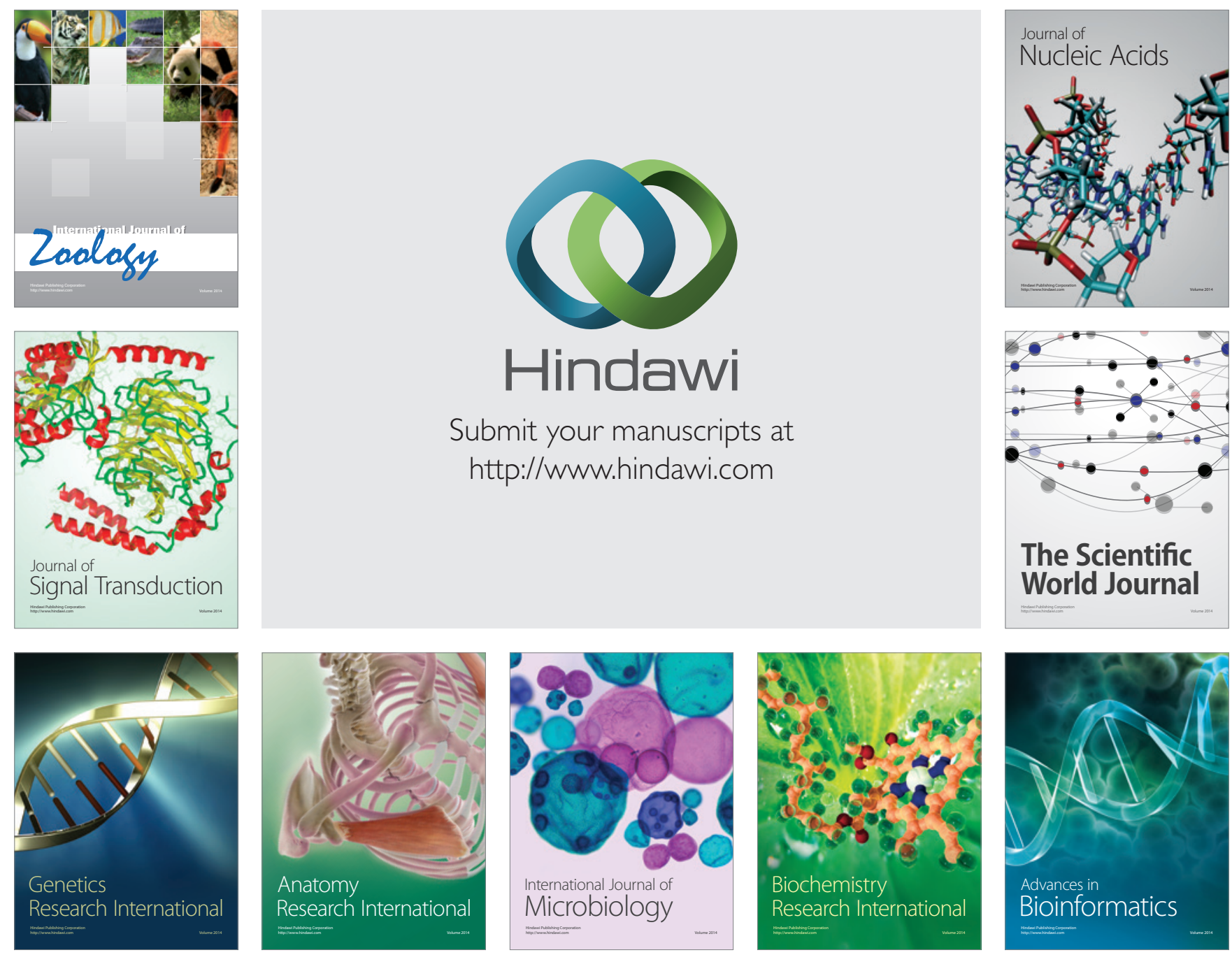

The Scientific World Journal
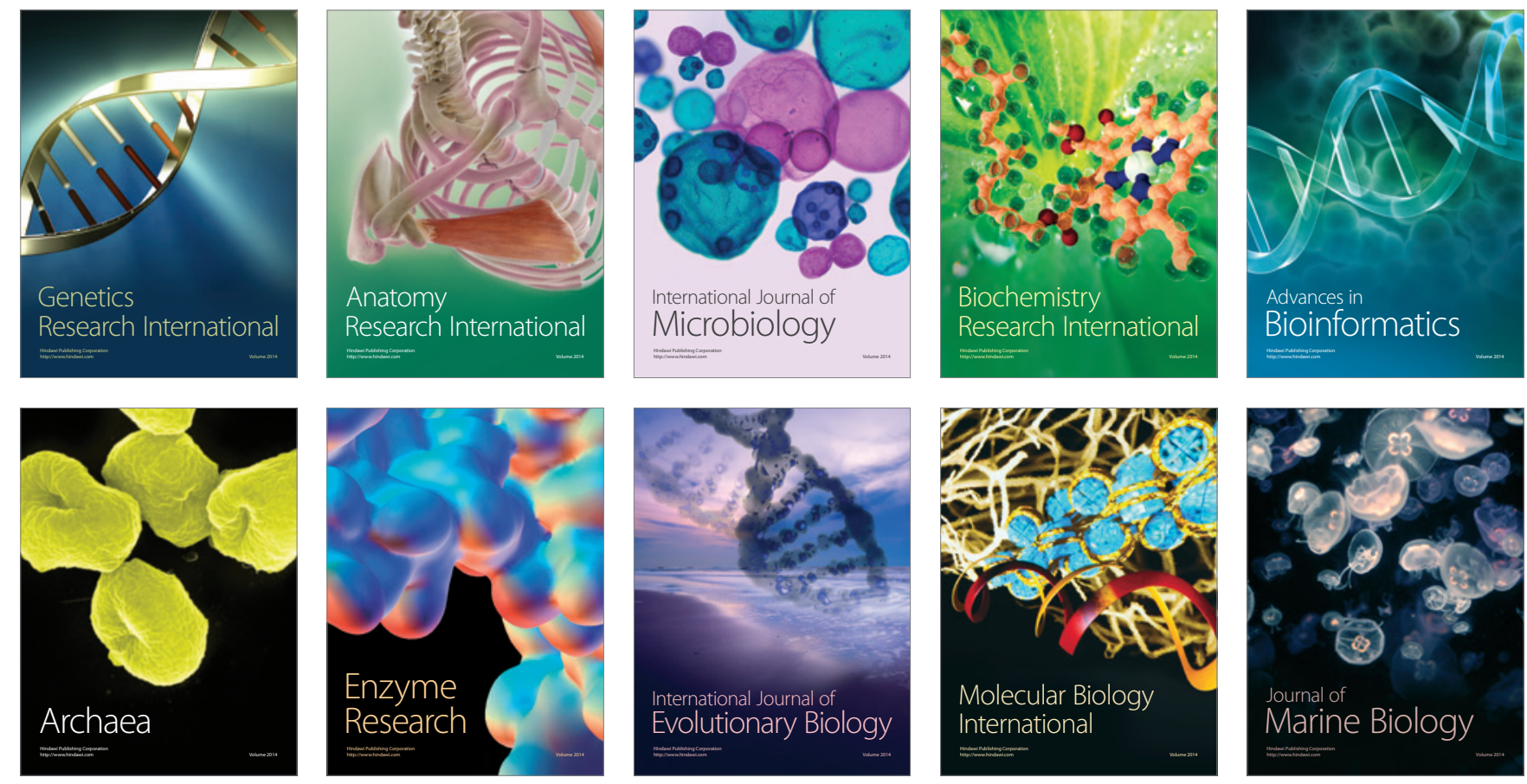